\title{
O potrzebie afiliacji jako pułapce w świecie mediów na przykładzie tekstów zamieszczanych w „Naszym Dzienniku”
}

„Potrzeba przynależności jest jedną z głównych ludzkich motywacji i niejednokrotnie modyfikuje zachowania. [...] Prawdopodobnie kształtując się w rozwoju filogenetycznym powodowała pozytywną selekcję osobników skłonnych do życia grupowego, co doprowadziło do tego, że stała się ona stałą cechą osobowości"'. Przynależność do grupy, stanowiąca, według Abrahama Maslowa, jedną z podstawowych potrzeb jednostki, ułatwia podejmowanie decyzji, redukuje lęk i sprzyja konformizmowi. Powoływanie się na przyjaźń, bliskie relacje ułatwia perswazję i manipulację, bowiem przeciwstawienie się wspólnocie grozi wykluczeniem. Potrzeba afiliacji stanowi pułapkę, ponieważ łatwo poddajemy się wpływom, by uzyskać poczucie bezpieczeństwa wynikające $\mathrm{z}$ akceptacji.

Manipulację definiuję jako wywieranie wpływu na odbiorcę przez działanie na jego nieświadomość, zmierzające do kształtowania jego opinii i postaw, a w rezultacie wpływanie na zachowanie bądź atrybucję odwróconą polegającą na zmianie zachowania, która determinuje zmianę postawy. Przyjmuję zaproponowane przez Elżbietę Laskowską rozróżnienie manipulacji uczciwej, choć brzmi jak oksymoron, i nieuczciwej, mimo iż brzmi jak tautologia, bowiem nie zawsze wpływanie na odbiorcę odbywające się poza jego świadomością musi mieć dla niego negatywne skutki. Psycholog społeczny, Dariusz Doliński, uważa nawet, że bez manipulacji nie jest możliwa, w wielu przypadkach, psychoterapia. Efekt placebo bazuje przecież na nieświadomości leczonego i jego fałszywym przekonaniu.

${ }^{1}$ A. Grzywa, Pułapki manipulacji, Lublin 2006, s. 22.

2 E. Laskowska, Lingwista wobec zjawiska manipulacji językowej, w: Mechanizmy perswazji i manipulacji: zagadnienia ogólne, red. G. Habrajska, Łask 2007, s. 11. 
Jak wykazano, na podobnej zasadzie mogą być oparte efektywne terapie nikotynowe, terapie najróżniejszych fobii oraz terapie seksualne. We wszystkich tych przypadkach kluczowe jest jednak wprowadzenie klienta w błąd. Nie można mu przecież powiedzieć: dajemy ci teraz tabletkę placebo, ale musisz uwierzyć, że spowoduje ona wzrost odczuwanego napięcia ${ }^{3}$.

Manipulacja jest określeniem ujemnie wartościowanym. Negatywna konotacja jest w Polsce dziedzictwem lat siedemdziesiątych i osiemdziesiątych XX wieku. Używając tego terminu, badacz może narazić się na zarzuty o brak postulowanej neutralności. Znawcy zjawiska sugerują posługiwanie się terminami niewartościującymi (zob. Anna Grzywa ${ }^{4}$, Irena Kamińska-Szmaj ${ }^{5}$, Robert-Vincent Joule, Jean-Leon Beauvois $\left.{ }^{6}\right)$. Aby wykluczyć nazwę konotującą ocenę, wprowadzam za Markiem Tokarzem terminy: perswazja jawna, która polega na „wyraźnym sformułowaniu rzeczywistego celu (!) perswazyjnego w samej wypowiedzi"7 , oraz perswazja niejawna, która takiego sformułowania nie zawiera.

W świecie czwartej władzy - mediów - istotne zdają się badania opisujące wpływ, jaki wywierają środki masowego przekazu na odbiorców. Próbę scharakteryzowania wyznaczników perswazji jawnej i niejawnej zawartej w tekstach dzienników podjęła Jolanta Sławek w wydanej w 2007 roku publikacji Czytelnik uwolniony? Perswazja we współczesnej informacji prasowej ${ }^{8}$.

Walery Pisarek zauważa, że ,w praktyce społecznej nie pojedyncze zdania, ale całe strumienie tekstów prasowych serwisów informacyjnych ukrywają za dominującą funkcją przedstawieniową kształtowanie naszego obrazu świata". Nadawcy bowiem rzadko udaje się wywrzeć wpływ na odbiorcę za pomocą jednego komunikatu. Kształtowanie opinii i postaw wymaga często złożonych komunikatów perswazyjnych, presji komunikacyjnej, sekwencji posunięć nakłaniających ${ }^{10}$. Strategie złożone polegające na wkradaniu się w łaski odbiorcy określa się zbiorczym terminem integracja, której celem jest uzyskanie sympatii odbiorcy. Badania Elliota Aronsona wykazały, że większy wpływ wy-

${ }^{3}$ D. Doliński, „Charaktery” 2008, z. 1, s. 27.

${ }^{4}$ A. Grzywa, op.cit.

${ }^{5}$ I. Kamińska-Szmaj, Propaganda, perswazja, manipulacja - próba uporzqdkowania pojęć, w: Manipulacja w języku, red. P. Krzyżanowski, P. Nowak, Lublin 2004.

${ }^{6}$ R.-V. Joule, J.-L. Beauvois, Gra w manipulację, przeł. E. Urscheler, Gdańsk 2006.

7 M. Tokarz, Argumentacja. Perswazja. Manipulacja, Gdańsk 2006, s. 207.

8 J. Sławek, Czytelnik uwolniony? Perswazja we współczesnej informacji prasowej, Poznań 2007.

${ }^{9}$ W. Pisarek, Perswazja - jak ja widza, jak ja pisza, w: Język perswazji publicznej, red. K. Mosiołek-Kłosińska, T. Zgółka, Poznań 2003, s. 14.

${ }^{10}$ Termin ten wprowadzam za M. Tokarzem. 
wierają komunikaty, których nadawcami są osoby lubiane przez odbiorców. Mechanizm asymilacji poglądów bądź kontrastowania zależy od nastawienia odbiorcy do nadawcy oraz od stopnia utożsamienia z systemem wartości grupy społecznej.

Tokarz twierdzi, że lubimy ludzi, którzy:

1) są atrakcyjni pod względem wyglądu zewnętrznego,

2) są do nas w jakiś sposób podobni,

3) pochlebnie się o nas wyrażają.

Podobny do odbiorcy pod jakimś względem nadawca wpływa na niego w większym stopniu. Wspólny system wartości - porozumienie aksjologiczne oraz zbieżność ideologiczna jednoczą, gdyż nie powodują dysonansu poznawczego. Anna Grzywa zauważa, iż „wydaje się zupełnie naturalne, że od własnej grupy ludzie oczekują więcej «dobrego» niż od osób spoza grupy. [...] W tym procesie istotną rolę odgrywa człon emocjonalny psychiki, który wytwarza przychylne i przepojone sympatią podłoże do spostrzegania osób pod jakimś względem bliskich"11.

Stanisław Barańczak wymienia cztery mechanizmy warunkujące skuteczne kształtowanie opinii i postaw, wszystkie związane z poczuciem więzi:

1) mechanizm emocjonalizacji odbioru,

2) mechanizm wspólnoty świata i wspólnoty języka,

3) mechanizm symplifikacji rozkładu wartości,

4) mechanizm bezalternatywnego odbioru ${ }^{12}$.

Mechanizm wspólnoty świata może sugerować, iż mamy do czynienia z zaproponowaną przez Aleksego Awdiejewa teorią nieantagonistyczną, która wyklucza perswazję niejawną ${ }^{13}$. Nadawca jednak, odwołując się do naturalnego bądź pozornego porozumienia aksjologicznego, może wytwarzać postawy. Należy bowiem pamiętać, że ,sprawny manipulator stara się poznać system wartości osoby manipulowanej po to, żeby pozornie dostosować się do niego, co sprawi, że stanie się dla tej osoby wiarygodny. Na pewno łatwiej damy się do czegokolwiek przekonać osobie, która ma system wartości taki, jak my, staje się nam bliska i dlatego uda się jej nami manipulować"14. Wytwarzanie postaw jest tożsame z kształtowaniem opinii nadawcy. Oznacza to, że przed podjęciem działań perswazyjnych odbiorca nie miał zdania na dany temat, gdyż nie miał okazji się z nim zetknąć bądź jego postawa w stosunku do danego obiektu, osoby czy zjawiska mieściła się w obszarze niezaangażo-

11 A. Grzywa, op.cit., s. 105.

12 S. Barańczak, Czytelnik ubezwłasnowolniony: perswazja w masowej kulturze literackiej PRL, Paryż 1983.

13 A. Awdiejew, Strategie konwersacyjne (próba typologii), „Socjolingwistyka” 1991, t. 11.

14 A. Grzywa, op.cit., s. 120. 
wania. Wyjątkowo mobilną sferą jest życie polityczne, które wymaga od jego uczestników ciągłego określania i wartościowania nowych obiektów realnych. Zjawisko przyswajania sądów i opinii grupy, do której należy jednostka, polegające na włączaniu nowych elementów postawy do postawy już istniejącej, psychologia określa mianem internalizacji.

Nadawca, włączając odbiorcę do kręgu wtajemniczonych, zaufanych, pokazuje, że tworzą wspólnotę. Przekazywanie informacji tajnych, zdradzanie „sekretów” ma działanie integrujące. Ponadto informacja niejawna wywiera większy wpływ na odbiorcę. Marek Tokarz zauważa, że ,informacja zakazana - czy to rzeczywiście, czy tylko w mniemaniu odbiorcy - ma większą siłę oddziaływania niż prawnie dozwolona" ${ }^{15}$. Jest to technika często wykorzystywana przez media.

Były szef klubu parlamentarnego PiS, jak dowiedzial się nieoficjalnie „Nasz Dziennik", ma wielką ochotę na powrót do sejmowych debat ${ }^{16}$.

Jak dowiedział się wczoraj nieoficjalnie „Nasz Dziennik”, śledczy sprawdzają informacje, które mogą w konsekwencji doprowadzić do miejsca pobytu Skowrońskiego ${ }^{17}$.

Informacjami na ten temat dysponują polskie służby specjalne - ustalil „Nasz Dziennik"18.

Służy temu również powoływanie się na tajne źródło, informatora, który ma dostęp do nieoficjalnych wiadomości:

Rozmowy prowadzone były nie tylko w Szwajcarii, ale również w Lichtensteinie. Mamy informacje, że również $\mathrm{w}$ tamtejszych bankach wpływowe osobistości polskiego życia politycznego mogły posiadać konta bankowe - mówi nasz informator $^{19}$.

Z przeprowadzonej kontroli wynika, że prokurator Niekrawiec zaakceptował wypłatę faktury za spotkanie integracyjne, które nigdy się nie odbyło. Wszystko wskazuje, że nie była to jedyna wystawiona „na wyrost” faktura. Sprawa ta jest $\mathrm{w}$ trakcie analizy - mówi nasz informator związany z Prokuraturą Krajową̨ ${ }^{20}$.

\footnotetext{
${ }_{15}$ M. Tokarz, op.cit., s. 225.

${ }^{16} \mathrm{http}: / /$ www.naszdziennik.pl/index.php?typ=po\&dat=20070420\&id=po01.txt.

${ }^{17} \mathrm{http} / / /$ www.naszdziennik.pl/index.php?typ=po\&dat=20070317\&id=po02.txt.

${ }_{18} \mathrm{http}: / /$ www.naszdziennik.pl/index.php?typ=po\&dat=20070308\&id=po01.txt.

$19 \mathrm{http} / /$ www.naszdziennik.pl/index.php?typ=po\&dat=20070524\&id=po01.txt.

${ }^{20} \mathrm{http}: / /$ www.naszdziennik.pl/index.php?typ=po\&dat=20070719\&id=po01.txt.
} 
Zgodność poglądów może być, jak wspomniano, naturalna bądź pozorna, działa jednak integrująco. Nadawca wyznający podobny system wartości do tego, którym kieruje się odbiorca, zyskuje jego aprobatę. Grzywa zauważa, że

potrzeba aprobaty, akceptacji otoczenia, zwłaszcza grupy, do której jednostka należy, jest istotnym regulatorem ludzkiego zachowania. Znana jest obserwacja, że ludzie w życiu społecznym selektywnie dobierają sobie takich partnerów, którzy podtrzymują ich poczucie własnej wartości przez udzielenie im pozytywnych ocen, jak też przez wyrażanie zgodności z ich poglądami ${ }^{21}$.

Opinie potwierdzające nasze sądy podnoszą samoocenę, nie wywołują dysonansu poznawczego, zapewniają więc nadawcy bezalternatywny odbiór. Stopień akceptacji innych osób, również nadawców komunikatów masowych, zwiększa się wraz ze stopniem podobieństwa systemów przekonań i maleje wraz ze wzrostem różnic.

Jeśli przekaz nadawcy nie jest w sprzeczności z opinią odbiorcy, zostaje asymilowany, ulega więc aproksymacji pozytywnej. Jeśli jednak jest niezgodny z wiedzą odbiorcy na dany temat, zostaje odrzucony, ulega aproksymacji negatywnej, gdyż mógłby zakłócić poczucie bezpieczeństwa, wywołując dysonans poznawczy. Nadawca może więc zmieniać postawy i opinie względem obiektów, osób i grup, które są dla odbiorcy nowe, a stanowisko odbiorcy względem nich znajduje się w obszarze neutralnym. Nadawca może również poszerzać obszary, w których znajdują się dane obiekty, zwiększając bądź zmniejszając obszar akceptacji lub odrzucenia, przy czym zmiana obszaru neutralnego zwykle dokonuje się na korzyść obszaru odrzucenia ${ }^{22}$.

$\mathrm{W}$ aspekcie socjologicznym przyjaźń nierozerwalnie związana jest z nieprzyjaźnią. „Aby wzmocnić poczucie więzi odbiorcy z tym światem, przedstawia się go jako zagrożony, a przez to wymagający obrony - zagrożony przez świat innych wartości - antywartości (świat onych)" ${ }^{923}$. Nie od dziś bowiem wiadomo, że wspólny wróg jednoczy. Figurę wroga wykorzystywała już marcowa propaganda. Był to, podobnie jak dziś, wróg, z którym należy walczyć wszelkimi sposobami i wszelkimi sposobami go demaskować. Im więcej wrogów, tym większa mobilizacja odbiorców. Im większy lęk, tym większa potrzeba afiliacji.

${ }^{21}$ A. Grzywa, Pułapki manipulacji, Lublin 2006, s. 44.

${ }^{22}$ Zob. M. Tokarz, op.cit., s. 80.

${ }^{23}$ K. Kłosińska, Rola procesów nominacyjnych w tworzeniu opozycji ,,my” $i$,,oni” w języku polityki po 1989 roku, w: Manipulacja w języku, red. P. Krzyżanowski, P. Nowak, Lublin 2004, s. 116. 
Łatwiej sterować ludźmi mającymi uprzedzenia przez odwołanie się do ich lęków. Autorzy tekstów adresowanych do odbiorców o skrajnych poglądach, bazują na tych skłonnościach, ponieważ obszar odrzucenia u takich osób jest większy niż obszar akceptacji. Skrajniejszym poglądom towarzyszy zazwyczaj większe osobiste zaangażowanie, które warunkuje emocjonalny odbiór. Nadawcy odwołują się więc do stereotypowego myślenia odbiorców oraz ich oczekiwań, wykorzystując argumentację aksjologiczną, ponieważ wartościowanie jest nierozerwalnie związane z emocjami. Dokonana przez J. Sławek analiza 4500 tekstów dzienników ukazujących się na polskim rynku pozwoliła na wysnucie wniosku, że ,ze słownictwa nacechowanego ekspresywnie najczęściej korzystają dziennikarze «Naszego Dziennika» i «Trybuny», przy czym należy zaznaczyć, iż dominuje tu wartościowanie negatywne, wywołujące skrajne emocje"24. Negatywnie nacechowana leksyka odzwierciedla się przez nazwy - etykietki, zazwyczaj dyskwalifikujące przeciwnika.

Naczelnym twórcą etykietek w „Naszym Dzienniku” jest prof. Jerzy Robert Nowak. Donald Tusk zyskał przydomek podważający jego prawdomówność - kłamliwy ${ }^{25}$. Stefan Niesiołowski określany jest mianem kameleon, ze względu na zauważoną przez autora etykietki częstą zmianę poglądów. Tytuł artykułu niedzielnego wydania „Naszego Dziennika” brzmi: Wybryki kameleona S. Niesiołowskiego ${ }^{26}$.

Katarzyna Kłosińska uważa, że „«zaklejanie» świata przez etykietki nie tylko utrwala i wyostrza podziały, lecz także niesie poczucie zagrożenia" ${ }^{27}$. Jednak poczucie zagrożenia u odbiorcy jest pożądane przez nadawcę, ponieważ implikuje chęć uczestniczenia we wspólnocie. Lęk zwiększa potrzebę afiliacji.

W kręgu jednostek zjednoczonych wizją wspólnego wroga nie trzeba wyjaśniać, tłumaczyć i dopowiadać. „Wtajemniczonym” wystarczą określenia uogólniające, wskazujące na zjawiska łatwo utożsamiane przez odbiorcę. Do tej grupy należą wyrażenia: pewne, określone i wiadome:

Sposób poprowadzenia sprawy dowodzi, że mieliśmy do czynienia ze zorganizowanym działaniem, za którym kryły się określone cele polityczne ${ }^{28}$.

Z drugiej strony, są też pewne trendy, tematy, pewne środowiska się promuje, innych się nie promuje. Oscara w kategorii filmów nieanglojęzycznych otrzymał

\footnotetext{
${ }^{24}$ J. Sławek, op.cit., s. 146.

${ }^{25} \mathrm{http} / /$ www.naszdziennik.pl/index.php?typ=my\&dat=20071012\&id=my21.txt.

${ }^{26} \mathrm{http} / /$ www.naszdziennik.pl/index.php?typ=my\&dat=20071229\&id=my19.txt.

${ }^{27}$ K. Kłosińska, Rola procesów nominacyjnych..., s. 120.

${ }^{28} \mathrm{http}: / /$ www.naszdziennik.pl/index.php?typ=po\&dat=20070627\&id=po01.txt.
} 
film „Fałszerze”, który dotyczy - jak czytamy w internecie - „genialnych żydowskich fałszerzy banknotów" ${ }^{\prime 29}$.

Kategoryzacja świata, podział na jasno zdefiniowane my i niejasno określone oni pomaga sterować opiniami odbiorcy. Nadawca i odbiorca stanowią wspólnotę. Nadawca zdaje się wskazywać, że ja i ty stanowimy my. Reszta to oni.

Znaczenie zaimka „oni” wypływa z tego, że oni to nie-my ani nie-wy - oni to tamci. Nadawca, który przyporządkowuje bohatera swojej wypowiedzi do grupy onych, określa go zwykle negatywnie: oni są najczęściej gorsi. Oni są szwedzkim stołem dla naszych negatywnych fantazji. [...] Onych jest wielu - im więcej ich jest, tym bardziej mobilizują odbiorców [...]. Zaimek „my” zawsze retorycznie amplifikuje, wzmacnia, zaimek „oni” zaś pomniejsza we wszystkich wymiarach, także moralnym. [...] Oni jako tamci poza naszym terytorium są daleko, więc są nieodróżnialni: liberały, aferały, pedały. Oni oczywiście chcą nam zaszkodzić. Ponieważ Oni są zdefiniowani negatywnie, rozmyci, mogą być naznaczeni wykluczającymi się cechami. Naturalną konsekwencją określania przeciwnika, który został zdefiniowany jako należący do Onych, jest jego niszczenie i dyskredytowanie. Polak nie musi wiedzieć, kim jest, ważne, żeby wiedział, kim nie ma być - ma nie być Onym, wtedy pozostanie Swojakiem ${ }^{30}$.

Wprowadzenie określenia środowiska sugeruje, że wrogów jest więcej i są zjednoczeni.

Od wielu lat prawie 40-milionowy Naród Polski pada w stopniu większym od innych narodów ofiarą kampanii oszczerczych pomówień, głównie ze strony niektórych polakożerczych środowisk niemieckich, żydowskich i rosyjskich ${ }^{31}$.

Na katolickich uczelniach w Stanach Zjednoczonych środowiska gejowskie przeprowadzają ponadto różnego rodzaju ankiety, z założenia mające propagować nienaturalne zachowania ${ }^{32}$.

Środowiska proaborcyjne w Wielkiej Brytanii prowadzą kampanię mającą na celu doprowadzenie do sytuacji, w której obniżona zostałaby - i tak już niska granica wieku inicjacji seksualnej młodzieży. Czynią to pod pretekstem zmniejszania liczby ciąż u nastolatek ${ }^{33}$.

\footnotetext{
${ }^{29} \mathrm{http}: / /$ www.naszdziennik.pl/index.php?typ=k1\&dat=20080226\&id=k111.txt.

30 J. Wasilewski, Retoryka dominacji, Warszawa 2006, s. 160.

${ }^{31} \mathrm{http} / /$ www.naszdziennik.pl/index.php?typ=my\&dat=20070328\&id=my21.txt.

${ }^{32} \mathrm{http}: / /$ www.naszdziennik.pl/index.php?dat=20080424.

33 „Nasz Dzienik”, 19.09.2008.
} 
Negatywnie waloryzowanym, choć tylko na gruncie polskim, określeniem jest również lobby, wskazujące na zjednoczoną wokół złej sprawy grupę osób, które działają przeciw nam i naszym interesom.

Proaborcyjne lobby argumentuje, że wczesne uświadomienie pozwoli na zmniejszenie liczby aborcji dokonywanych u nastolatek ${ }^{34}$.

Nadawca, chcąc kształtować postawy i opinie odbiorcy, może oddziaływać za pomocą dwóch odmiennych trybów odbioru: centralnego i peryferyjnego. Centralny odwołuje się do logicznych argumentów, które poddane są przez odbiorcę uważnej analizie. Tor peryferyjny zakłada emocjonalizację odbioru, reakcje związane z przekazem i jego kontekstem. Jerzy Bralczyk uważa, że cecha bliskości ma najbardziej emocjonalny charakter. „Tu najwyraźniej dokonuje się próba wywołania u nadawcy identyfikacji" ${ }^{35}$. Emocjonalnej integracji z nadawcą służą nazwy określające grupę, wspólnotę, z którą odbiorca powinien się utożsamić. Rodzina Radia Maryja, która jest pokrewnym przedsięwzięciem medialnym „Naszego Dziennika”, wskazuje na bliski, niemalże związany pokrewieństwem charakter wspólnoty. Nauki społeczne nazywają tego rodzaju związki grupami pierwotnymi. „Ważną cechą każdej grupy (zwłaszcza nieformalnej) jest to, że wytwarza ona zwykle pewne normy i zasady postępowania, a także ma uzgodnione opinie, postawy i wartości, wokół których organizuje się myśli i działania jej członków"36. Chcąc należeć do Rodziny - zwłaszcza gdy ma ona charakter nieformalny, więc można zostać z niej wykluczonym - należy podzielać jej opinie, nawet wtedy, gdy nie jesteśmy pewni ich słuszności. Rodzina, jak zauważa Jerzy Bralczyk, jest jednym $\mathrm{z}$ najczęstszych słów-kluczy propagandy ${ }^{37}$.

Potęgowaniu wrażenia wspólnoty służy użyty w tytule dziennika zaimek dzierżawczy nasz, charakteryzujący się silnym ładunkiem emocjonalnym. „Nasz identyfikuje desygnat wyrazu określanego jako taki, z którym odbiorca identyfikować się powinien - i oczywiście podkreśla wspólność interesów i odczuć nadawcy i odbiorcy”"38. „Nasz Dziennik” opisuje sprawy dla nas ważne, nas dotyczące, używając często my inkluzywnego.

Zatrudniony w kancelarii premiera za nasze pieniądze sztab ludzi, którego zadaniem jest dbanie o wizerunek premiera i Platformy Obywatelskiej i wmówienie

\footnotetext{
34 „Nasz Dziennik”, 19.09.2008.

35 J. Bralczyk, O języku propagandy i polityki, Warszawa 2007, s. 150.

36 Ibidem, s. 102.

37 Ibidem, s. 159.

38 Ibidem, s. 156.
} 
społeczeństwu, iż Premier i Platforma dobrze rządzą, doszedł najwidoczniej do wniosku, że lepiej pochwalić się tym, nad czym się pracuje, niż tym, że nie pracuje, aby nie mnożyć niepotrzebnych przepisów ${ }^{39}$.

Nie przeszkodziło to jednak w tym, że cała publikacja stanowi swego rodzaju tendencyjny gniot antypolski, pełen tekstów deformujących zarówno dzieje Polski, jak i obraz naszej wspólczesności ${ }^{40}$.

Dalsze tak intensywne „,prace” obecnej ekipy sprawią, że przy okazji każdej skłaniającej do podsumowań rocznicy rządu będziemy karmieni obietnicami ${ }^{41}$.

Wzmocnieniu więzi służy często „My narodowe”, które „opiera się na strategii zapobieżenia pojawieniu się niepożądanego Ja odbiorcy, a tym samym - krytycznego stosunku do tego, co zawiera się w treści; nadawca sam wyrzeka się swego Ja i poświęca się sprawie wyrażania Jego uwspólnionych myśli i uczuć" 42 .

Katolicyzm, przywiązanie do tradycji i antysemityzm - to główne cechy przypisywane nam, Polakom, w zachodnich i wschodnich monografiach historycznych jako zasadnicze wady ${ }^{43}$.

Emocjonalny stosunek do przedmiotu wypowiedzi prowadzi do otwarcia odbiorcy na argumentację aksjologiczną. Akty emotywne są często wykorzystywane do manipulowania przekazem, bowiem, jak zauważa Grażyna Habrajska,

emocja nadawcy jest pewną nadwyżką, która w procesie interakcji werbalnej pomaga mówiącemu w przekonaniu odbiorcy do przyjęcia proponowanej oceny, ponieważ na mocy konwencji wymagającej solidarności uczuć, odbiorca nie ma możliwości odrzucenia wyrażonej emocji z taką samą łatwością, z jaką odrzuciłby samą ocenę nie popartą emocjami ${ }^{44}$.

Wszystkie te zabiegi stosowane są, aby spotęgować emocjonalny odbiór tekstów, który umożliwia dotarcie komunikatu torem peryferyjnym. Emocjo-

39 „Nasz Dziennik”, 13-14.09.2008.

40 Ibidem.

${ }^{41}$ Ibidem.

42 J. Wasilewski, op.cit., s. 157.

43 „Nasz Dziennik”, 13-14.09.2008.

${ }^{44}$ G. Habrajska, Manipulacja za pomocq aktów emotywnych, w: Mechanizmy perswazji i manipulacji: zagadnienia ogólne, red. G. Habrajska, Łask 2007, s. 116. 
nalizacja odbioru często wzmacniana jest użyciem języka potocznego, zwanego przez Małgorzatę Kitę ,językiem bliskości”"45. Potocyzmy wywołują bowiem poczucie swojskości, naturalności, bliskości. Polszczyzna potoczna jest również bogato wyposażona w składniki emocjonalne, warunkujące odbiór torem peryferyjnym.

Stylu potocznego pisanego celowo używa się w prasie. Redaktor „Gazety Wyborczej”, Krzysztof Śliwiński, w następujący sposób tłumaczy codzienność języka dziennika:

Pragniemy do religii i Kościoła podchodzić poważnie, w sposób naturalny, pisząc zwykłym codziennym językiem - nie Ojciec Święty, lecz po prostu papież, nie że premier przyjął Przenajświętszą Eucharystię, lecz Komunię świętą itd. itd. Czytelnik [...] powinien odnosić wrażenie, że pisze się do niego po ludzku, normalnie - o każdej sprawie ${ }^{46}$.

Emocjonalizacji przekazu służą też znaki interpunkcyjne, zwłaszcza wykrzyknik:

Opanujcie się! ${ }^{47}$

Jerzy Bartmiński zauważa, że

styl potoczny - jak każdy styl - przekazuje i utrwala pewien obraz świata, nazywany zwykle obrazem ,naiwnym” [Apresjan 1980, s. 79-80]. Obraz ten jest budowany z punktu widzenia ,prostego człowieka”, odpowiada postawie zdroworozsądkowej, a znajduje swój wyraz zarówno w strukturze słownictwa i jego organizacji semantycznej, frazeologizmach i przysłowiach, jak też w zespole kategorii gramatycznych, regułach derywacji, wzorcach budowy zdań, sposobach budowania tekstów ${ }^{48}$.

Emocjonalno-kolokwialny rejestr języka potocznego sprzyja kategoryzacji oraz używaniu leksyki wartościującej. Jolanta Sławek podkreśla, że leksyka prymarnie wartościująca jest charakterystyczna dla dzienników prezentujących radykalne poglądy ${ }^{49}$. Należy jednak pamiętać, że większość słownictwa

${ }^{45}$ M. Kita, Język potoczny jako język bliskości, w: Język w komunikacji, t. 1, red. G. Habrajska, Łódź 2001.

${ }^{46}$ K. Śliwiński, wywiad dla „Przekroju” 1989, nr 2321-2323, s. 39.

${ }^{47} \mathrm{http} / /$ www.naszdziennik.pl/index.php?typ=dd\&dat=20070628\&id=main.

48 J. Bartmiński, Styl potoczny, w: Potoczność w języku i kulturze, red. J. Anusiewicz, F. Nieckula, Wrocław 1991, Język a Kultura, t. 5, s. 40.

${ }^{49}$ J. Sławek, op.cit. 
potocznego wartościuje ujemnie. Użytkownikami tego stylu są zwykli ludzie, których przeciwstawić można elicie:

Fałsz, obłuda elit i mediów sięgnęły zenitu ${ }^{50}$.

Potrzeba nawiązywania i podtrzymywania kontaktów społecznych stanowi jedną z podstawowych potrzeb psychologicznych jednostki. Niebezpieczeństwo konformizmu towarzyszące potrzebie społecznej akceptacji jest nieodzowne. Nadawca, chcąc skłonić odbiorcę do opinii, postaw i zachowań powszechnie akceptowanych, może odwoływać się do wielkich kwantyfikatorów, wśród których wymienić można zwroty wyrażające powszechność: wszy$s c y, k a \dot{z} d y$.

Wskazywaniu powszechności sądów służą operatory, występujące w formie częściowo związanych gramatycznie frazemów, odwołujące się do wiedzy ogólnej: powszechnie wiadomo, wszyscy wiedza:

Wszystkim wiadomo, że trudności życia społecznego, dolegliwości i cienie nie są nigdy do uniknięcia w całości, zarówno w dziedzinie materialnej, jak i duchowej $^{51}$.

Grupa ITI (International Trading and Investments Holdings SA Luxembourg) to holding medialny założony w 1984 roku przez Jana Wejcherta i Mariusza Waltera jako jedna z pierwszych prywatnych firm w Polsce. Otrzymała ona od ówczesnych władz koncesję na import sprzętu elektronicznego i rozprowadzanie kaset wideo w Polsce. Jak wiadomo, w tamtych czasach komuniści nie rozdawali takich przywilejów bezinteresownie, a i beneficjenci raczej nie korzystali z nich zupełnie za darmo ${ }^{52}$.

Perswazja jawna i niejawna mają nieostre granice. Trudno więc stwierdzić, gdzie kończy się ta pierwsza, mająca neutralną konotację (choć nie dla wszystkich, bowiem Tadeusz Zgółka zauważa, że zjawisku perswazji towarzyszy często filtr aksjologiczny - nadawca nie chciałby być obiektem, przedmiotem perswazji, sam jednak mógłby być perswadującym) ${ }^{53}$, a gdzie zaczyna się manipulacja wartościowana negatywnie. Trudno również orzec, czy wspólnota poglądów prezentowanych przez nadawców jest neutralna, więc odwołuje się do wspólnej przestrzeni aksjologicznej, czy pozorowana, która sugeruje in-

\footnotetext{
${ }^{50} \mathrm{http}: / /$ www.naszdziennik.pl/index.php?typ=dd\&dat=20070628\&id=main.

${ }^{51} \mathrm{http}: / /$ www.naszdziennik.pl/index.php?typ=my\&dat $=20081025 \& \mathrm{id}=\mathrm{my3}$.txt.

${ }^{52} \mathrm{http}: / /$ www.naszdziennik.pl/index.php?typ=my\&dat=20070526\&id=my41.txt.

${ }^{53}$ Język perswazji publicznej, red. K. Mosiołek-Kłosińska, T. Zgółka, Poznań 2003.
} 
gracjację. Można jednak wskazać wyznaczniki perswazji jawnej i niejawnej, zabiegi integrujące, operatory perswazyjne, które ułatwiają wywarcie wpływu na odbiorcę. Takie działanie mają wymienione i opisane wyżej środki. Leksyka wartościująca jest nierozerwalnie związana z emocjonalizacją odbioru, która otwiera tor peryferyjny. My inkluzywne zjednuje, włącza do wspólnoty, która zaspokaja potrzebę psychologiczną jednostki - potrzebę kontaktu emocjonalnego. Zaimek dzierżawczy nasz wywołuje identyfikację odbiorcy, wskazując na wspólnotę świata. Język potoczny wprowadza wrażenie bliskości, swojskości. Kategoria bliskości jest charakterystyczna dla języka perswazji i propagandy, ponieważ emocjonalizuje przekaz i ułatwia akceptacyjny odbiór. Typizacja potoczna angażuje zarówno kryteria poznawcze, obiektywne, jak i kryteria emocjonalne, oparte na wartościowaniu. Typizacja owocuje pewną stabilnością wizji świata, oznacza preferencje dla wspólnotowego (,solidarnościowego"), a nie indywidualistycznego widzenia rzeczywistości ${ }^{54}$. Język ezopowy, widoczny w tekstach o charakterze perswazyjnym, jest realizowany przez określenia uogólniające, oceniane przez J. Bralczyka jako wyrazy mające w pewien sposób charakter indeksalny, „odsyłają bowiem odbiorcę do jakichś łatwo jakoby przez niego utożsamianych zjawisk, nie charakteryzując ich bynajmniej, co najwyżej dając znać temu, kto owładnął konwencją TP, że są to zjawiska negatywne" ${ }^{55}$. Wśród nich wymienić można wyrażenia: określone, wiadome, pewne (zawsze w liczbie mnogiej) ${ }^{56}$. Wszystkie te zabiegi maja na celu integrację, która stanowi pułapkę dla odbiorcy. Grażyna Habrajska uważa, że „solidarność uczuć, oparta na zasadzie wzajemności, ułatwia forsowanie trudnych do przyjęcia sądów, których nadawca nie potrafi udowodnić za pomocą merytorycznych argumentacji i kontrowersyjnych opinii, naruszających system ideologiczny odbiorcy"57.

Jeśli porozumienie aksjologiczne jest pozorowane, nadawca, odwołując się do niego, może wpłynąć na neutralną sferę poglądów odbiorcy i wykształcić pożądane postawy i opinie, dążąc do zmiany zachowania. Jest więc perswazja formą zniewalania umysłu odbiorcy, a przecież $\dot{z}^{58} n i k t^{59}$ nie chce być zniewolony, $k a z d y^{60}$ chce świadomie decydować.

${ }^{54}$ Ibidem, s. 49.

55 J. Bralczyk, op.cit., s. 40.

${ }^{56}$ Ibidem, s. 171.

${ }^{57}$ G. Habrajska, op.cit., s. 116.

${ }^{58}$ Metaoperator perswazyjny blokujący weryfikację. Podaję za: A. Awdiejew, Systemowe środki perswazji, w: Manipulacja w języku, red. P. Krzyżanowski, P. Nowak, Lublin 2004, s. 71-80.

${ }^{59}$ Mały kwantyfikator. Podaję za: ibidem.

${ }^{60}$ Wielki kwantyfikator wprowadzający powszechność. Podaję za: ibidem. 
Potrzeba afiliacji jest silna. Dla niektórych jednostek stanowi podstawową potrzebę psychologiczna. Przynależność do większej grupy odbiorców podnosi samoocenę, wskazuje bowiem na słuszność wyznawanych poglądów. Jednak zabiegi integracyjne są najczęściej wykorzystywaną metodą wywierania wpływu. Nadawca odwołuje się do wspólnego horyzontu interpretacyjnego oraz porozumienia aksjologicznego, by umożliwić emocjonalizację odbioru i dotarcie do odbiorcy torem peryferyjnym. Odbiorca powinien zatem pamiętać, że zasada lubienia oraz zasada społecznego dowodu słuszności stanowią pułapkę, bowiem

wszystkie te racjonalne wywody, na które natrafimy w prasie czy mediach elektronicznych, uzasadniane potrzebą polityki informacyjnej, mają silne podłoże emocjonalne, wyraźnie podtrzymywane przez leksykę i frazeologię, umiejętnie, bo niejawnie podpowiadająca, co jest dobre, a co złe: wszyscy wolimy przecież być $\mathrm{z}$ rodziną niż poza nią i nikt nie chce czuć się człowiekiem z marginesu ${ }^{61}$.

\section{Marta Szymborska}

\section{On the Need of Affiliation as a Trap in the World of Media on the Example of Texts Published in Nasz Dziennik}

The media, while fulfilling the needs of individuals, may also influence people. A fundamental and relevant psychological need is the desire for acceptance and, connected with it, the need for affiliation. The enhancement of self-esteem achieved by gaining support for the professed opinions, the feeling of security resulting from being a member of a particular group, which eliminates fear, may lead to conformism. The addressor, willing to influence the recipient, can refer to their common interpretative horizon, axiological agreement and common good, thus, by means of ingratiation, can bring about a change in the recipient's attitude. The aim of the article is to indicate integrative linguistic devices applied by mass media which make the persuasive action easier. Referring to friendship makes persuasion and manipulation much more simple; opposing the community may result in exclusion.

${ }^{61}$ J. Warchala, Horyzonty manipulacji: perswazja, manipulacja, interpretacja, w: Manipulacja w języku, red. P. Krzyżanowski, P. Nowak, Lublin 2004, s. 47. 
